\title{
Chemical Composition and Insecticidal Activities of Essential Oils of Myrtaceae against Tribolium castaneum (Coleoptera: Tenebrionidae)
}

\author{
Saima Siddique ${ }^{1 *}$, Zahida Parveen ${ }^{3}$, Firdaus-e-Bareen ${ }^{2}$, Abida Butt ${ }^{4}$, \\ Muhammad Nawaz Chaudhary ${ }^{1}$, Muhammad Akram ${ }^{5}$ \\ ${ }^{1}$ College of Earth and Environmental Sciences, University of the Punjab, 54890-Lahore, Pakistan \\ ${ }^{2}$ Department of Botany, University of Punjab, Lahore-54890, Pakistan \\ ${ }^{3}$ Applied Chemistry Research Centre, PCSIR Laboratories Complex, Lahore-54600, Pakistan \\ ${ }^{4}$ Department of Zoology, University of the Punjab, 54890-Lahore, Pakistan \\ ${ }^{5}$ Medicinal Botanic Centre, PCSIR Laboratories Complex, Peshawar-25000, Pakistan
}

Received: 22 April 2017

Accepted: 15 May 2017

\begin{abstract}
The present study was designed to determine chemical composition of essential oils extracted from different species of the Myrtaceae family and to evaluate their insecticidal activities against Tribolium castaneum (Coleoptera: Tenebrionidae). The essential oils of 10 species were extracted by hydrodistillation and analyzed by a gas chromatography-flame ionization detector (GC-FID) and gas chromatography-mass spectrometry (GC-MS). The main component of Eucalyptus crebra, E. microtheca, E. rudis and Melaleuca quinquenervia essential oils was 1,8-cineole (31.6-49.7\%). E. melanophloia and E. tereticornis contained p-cymene (41.8-58.1\%) as a major component, while Eucalyptus kitsoniana and E. pruinosa essential oils were dominated by $\alpha$-pinene (25.8-31.4\%). Eugenol methyl ether was identified as a major component in M. bracteata essential oil (82.3\%). $\alpha$-Pinene (31.4\%) was the main component in the $C$. viminalis essential oil. Essential oils of all selected plant species showed good insecticidal activities against $T$. castaneum when compared with pyrethroid as a positive control. Eucalyptus rudis proved most potent against T. castaneum, followed by M. bracteata, M. quinquenervia, and C. viminalis. The results of this study indicate that essential oil of Myrtaceae leaves have potential to be used in the control of T. castaneum.
\end{abstract}

Keywords: 1,8-cineole, E. melanophloia, hydro-distillation, GC-MS, $\mathrm{LC}_{50}$, M. quinquenervia, $\alpha$-pinene

*e-mail: saimesiddique@gmail.com 


\section{Introduction}

Wheat (Triticum aestivum L.) is the major source of protein in human foods and the second main food crop in terms of production [1]. More than 2,000 species of pestiferous insects annually destroy approximately one third of the world wheat production, valued at more than $\$ 100$ billion [2]. Synthetic chemical insecticides and fumigants are commonly used to manage pestiferous insects throughout the world. Fumigants are preferred as they are convenient to use, economical, and have broad spectrum action and rapid penetration into the commodity [3]. However, the use of synthetic insecticides and fumigants lead to the problems of residual toxicity in non-targeted organisms, development of resistance and resurgence in pestiferous insect populations, adverse environmental impacts such as ozone depletion, pollution, etc. [4]. These problems have necessitated the search for alternative ecologically safe insect pest control methods. Plant-derived insecticides have gained attention in recent years in the pest management industry because of their low toxicity on mammals, short environmental persistence, minimal residual activity, and thus wide public acceptance [5].

Among plant-derived insecticides, essential oils are worth mentioning. They are secondary plant metabolites, aromatic in nature, and give a distinctive odour or flavour to a plant [6]. Chemically, they are complex mixtures comprised of a large number of constituents in variable ratios [7]. The effectiveness of essential oils and their components in the control of stored product pests has been well-established [8-11].

The Myrtaceae (Myrtales) family, comprising at least 133 genera, is a rich source of essential oils. It is found abundantly in Australia, Southeast Asia, and tropical to southern temperate America, while a few are domesticated in Africa [12]. The essential oils from Myrtaceae have demonstrated antibacterial, anti-inflammatory, fungicidal, antioxidant, and antiviral properties [13-15]. Studies have also reported insecticidal activities of different species of Myrtaceae against T. castaneum [16-18]. $\alpha$ and $\beta$-pinene, terpinen-4-ol, 1,8-cineole, and methyl eugenol have been reported as major components in Myrtaceae essential oils, which have been known for their toxicities against pestiferous insects [19-23].

Pakistan is the $9^{\text {th }}$ largest wheat-producing country, accounting for $3.0 \%$ of the world's wheat production from an area of $3.57 \%$ of the world [24]. The warm and moist climate of Pakistan is conducive to infestation of stored grains by different pests. Tribolium castaneum (Herbst) (Coleoptera: Tenibrionidae) is one of the most abundant and detrimental insects that affects stored grains [25]. Estimated weight loss during storage is approximately $4 \%$ in Pakistan and accounts for about 1,000 million rupees in losses contributing more than $24 \%$ to gross domestic product (GDP) each year [26]. Sun-drying, aluminium phosphine tablets, insecticides, and elemental mercury have been used to control pestiferous insects. Although some degree of control seems to have been achieved, most chemical treatments are unsatisfactory and can be dangerous to health. Pakistan is rich in medicinally and economically rich flora. Myrtaceae is represented by seven genera and 26 species in Pakistan [27]. Keeping in view the insecticidal properties of Myrtaceae and the need for natural fumigants, the present study was designed to explore chemical composition of oil extracted from 10 species (C. viminalis, E. crebra, E. kitsoniana, E. melanophloia, E. microtheca, E. pruinosa, E. rudis, E. tereticornis, M. bracteata, and M. quinquenervia) from Pakistan and to assess their insecticidal effects for their potential use as alternatives to chemical fumigants. The selection of species was made on the basis of their abundance and availability.

\section{Material and Methods}

\section{Chemicals}

Homologous series of $\mathrm{C}_{8}-\mathrm{C}_{25} n$-alkanes used in this study were obtained from Sigma Chemical Co. (St. Louis, MO, USA). Ethanol was purchased from Merck (Darmstadt, Germany).

\section{Plant Material}

Mature leaves of 10 selected species of Myrtaceae were collected from different localities around Pakistan (Table 1). Taxonomic authentication was performed by Prof. Dr. A. N. Khalid at the Herbarium, Department of Botany, University of Punjab, Lahore, Pakistan. Plant specimens were deposited in the same herbarium.

\section{Isolation of Oils}

From each plant, fresh leaves weighing $2 \mathrm{~kg}$ were hydrodistilled for 3 hours using a Clevenger-type apparatus according to the method recommended in the European Pharmacopoeia [28]. Oils were dried over anhydrous sodium sulfate, filtered, and stored at $-4^{\circ} \mathrm{C}$ in a freezer until analyzed. The essential oil contents (\%) were expressed as volume of essential oil vs.weight of fresh leaves $(\mathrm{v} / \mathrm{w})$.

\section{Chemical Analysis of Essential Oils}

\section{GC-FID}

GC analysis of the essential oils was carried out on a Shimadzu GC 2010 equipped with a flame ionization detector (FID) and AOC-20i autosampler using a DB-5 MS (30 $\mathrm{m} \times 0.25 \mathrm{~mm}$ id, $0.25 \mu \mathrm{m}$ film thickness) capillary column. The column oven temperature was programmed initially at $40-90^{\circ} \mathrm{C}$ at the rate of $2^{\circ} \mathrm{C} / \mathrm{min}$ and then raised to $90-240^{\circ} \mathrm{C}$ at the rate of $3^{\circ} \mathrm{C} / \mathrm{min}$. The final temperature was held constant for $5 \mathrm{~min}$. Injector and detector temperatures were maintained at 240 and $280^{\circ} \mathrm{C}$, respectively. Essential oil $(0.5 \mu \mathrm{l})$ was injected in 
Table 1. Detail of collected plants from different sites in Pakistan.

\begin{tabular}{|c|c|c|c|c|}
\hline Plant Name & Harvesting Month & Locality of Collection & GPS coordinates & Voucher Number \\
\hline Callistemon viminalis & October 2013 & $\begin{array}{l}\text { Qarshi Botanical garden, } \\
\text { Hattar, Abottabad }\end{array}$ & $\begin{array}{l}\text { Longitude } 72.85^{\circ} \mathrm{E}, \\
\text { Latitude } 33.85^{\circ} \mathrm{N}\end{array}$ & BDSS \#4055 \\
\hline Eucalyptus crebra & March 2013 & $\begin{array}{l}\text { Pakistan Forest Research } \\
\text { Institute, Faisalabad }\end{array}$ & $\begin{array}{l}\text { Longitude } 73.11^{\circ} \mathrm{E} \\
\text { Latitude } 31.28^{\circ} \mathrm{N}\end{array}$ & BDSS \#4023 \\
\hline Eucalyptus kitsoniana & March 2013 & $\begin{array}{l}\text { Pakistan Forest Research } \\
\text { Institute, Faisalabad }\end{array}$ & $\begin{array}{l}\text { Longitude } 73.11^{\circ} \mathrm{E} \\
\text { Latitude } 31.28^{\circ} \mathrm{N}\end{array}$ & BDSS \#4024 \\
\hline Eucalyptus melanophloia & March 2013 & $\begin{array}{l}\text { Pakistan Forest Research } \\
\text { Institute, Faisalabad }\end{array}$ & $\begin{array}{l}\text { Longitude } 73.11^{\circ} \mathrm{E} \\
\text { Latitude } 31.28^{\circ} \mathrm{N}\end{array}$ & BDSS \#4025 \\
\hline Eucalyptus microtheca & March 2013 & $\begin{array}{l}\text { Pakistan Forest Research } \\
\text { Institute, Faisalabad }\end{array}$ & $\begin{array}{l}\text { Longitude } 73.11^{\circ} \mathrm{E}, \\
\text { Latitude } 31.28^{\circ} \mathrm{N}\end{array}$ & BDSS \#4026 \\
\hline Eucalyptus pruinosa & March 2013 & $\begin{array}{l}\text { Pakistan Forest Research } \\
\text { Institute, Faisalabad }\end{array}$ & $\begin{array}{c}\text { Longitude } 73.11^{\circ} \mathrm{E}, \\
\text { Latitude } 31.28^{\circ} \mathrm{N}\end{array}$ & BDSS \#4027 \\
\hline Eucalyptus rudis & March 2013 & $\begin{array}{l}\text { Pakistan Forest Research } \\
\text { Institute, Faisalabad }\end{array}$ & $\begin{array}{l}\text { Longitude } 73.11^{\circ} \mathrm{E}, \\
\text { Latitude } 31.28^{\circ} \mathrm{N}\end{array}$ & BDSS \#4028 \\
\hline Eucalyptus tereticornis & March 2013 & $\begin{array}{l}\text { Pakistan Forest Research } \\
\text { Institute, Faisalabad }\end{array}$ & $\begin{array}{c}\text { Longitude } 73.11^{\circ} \mathrm{E}, \\
\text { Latitude } 31.28^{\circ} \mathrm{N}\end{array}$ & BDSS \#4029 \\
\hline Melaleuca bracteata & April 2013 & $\begin{array}{c}\text { Government College } \\
\text { University botanical garden, } \\
\text { Lahore }\end{array}$ & $\begin{array}{l}\text { Longitude } 74.31^{\circ} \mathrm{E}, \\
\text { Latitude } 31.57^{\circ} \mathrm{N}\end{array}$ & BDSS \#4040 \\
\hline Melaleuca quinquenervia & October 2013 & $\begin{array}{l}\text { Pakistan Horticulture Authority } \\
\text { botanical garden, Lahore }\end{array}$ & $\begin{array}{l}\text { Longitude } 74.30^{\circ} \mathrm{E} \\
\text { Latitude } 31.50^{\circ} \mathrm{N}\end{array}$ & BDSS \#4042 \\
\hline
\end{tabular}

a split-mode ratio of 1:5. Helium was used as a carrier gas at a flow rate of $1 \mathrm{ml} / \mathrm{min}$. Quantification of constituents was done by integration of peak areas without using correction factors.

\section{GC-MS}

The identification of components was carried out on a GCMS-QP 2010 Plus (Shimadzu, Japan) operating in electron ionization mode at $70 \mathrm{eV}$. Mass units were monitored from 35 to 500 AMU. A DB-5 MS $(30 \mathrm{~m} \times 0.25 \mathrm{~mm}$ id, $0.25 \mu \mathrm{m}$ film thickness) capillary column was used. Column conditions and injector and detector temperatures were the same as in GC analysis.

Linear retention indices were calculated using a homologous series of $n$-alkanes $\left(\mathrm{C}_{8}-\mathrm{C}_{25}\right)$ under the same temperature-programmed conditions. The components were identified by comparison with linear retention indices (RI) from literature, mass spectra with those of NIST mass spectral library, or co-injection with standards [29-30].

\section{Collecting Insects}

Tribolium castaneum adults were obtained from the laboratory cultures (Department of Zoology, University of Punjab) maintained in the dark in an incubator at $30 \pm 1^{\circ} \mathrm{C}$ and $60 \pm 5 \%$ relative humidity. Insects were reared on wheat flour mixed with yeast (10:1) containing 12-13\% moisture content. Adult unsexed insects, 7-14 days old, were used in the bioassay.

\section{Toxicity as Fumigant}

The activity of essential oils against $T$. castaneum was evaluated using the method of Pires et al., (2006) [31].

Different concentrations of essential oils were selected on the basis of preliminary tests. Tested concentrations of oils ranged from 2-25 $\mu$ l for Eucalyptus species and 0.4-0.9 $\mu \mathrm{l}$ for Melaleuca and Callistemon species. The filter paper discs (2 cm diameter, Whatman No. 10, Sigma Aldrich) were impregnated with different oils using micropipette (Gilson, Inc.). Then treated discs were attached to the under surface of the screw cap of a glass container $(22 \mathrm{ml})$ and assumed $100 \%$ volatilization of the oils in the container. Ten 7-14-day-old T. castaneum adults were placed in each container with $0.5 \mathrm{~g}$ of wheat flour as food before capping. The control groups consisted of a similar setup without the disc of essential oil. The experiment was conducted at $30 \pm 1^{\circ} \mathrm{C}$ and $65 \pm 5 \%$ relative humidity. Mortality of $T$. castaneum adults was recorded after $4,8,12$, and $24 \mathrm{~h}$ from commencement of exposure. Insects were considered dead if they showed no leg or antennal movements on touch with fine brush. For bioassay, 6-8 concentrations of essential oil from each species of Myrtaceae were used. Each concentration and control was replicated 10 times.

\section{Statistical Analysis}

Hierarchical cluster analysis was done on the basis of the percentage composition of essential oils (with compounds of $>0.1 \%$ ). A dendrogram was obtained 


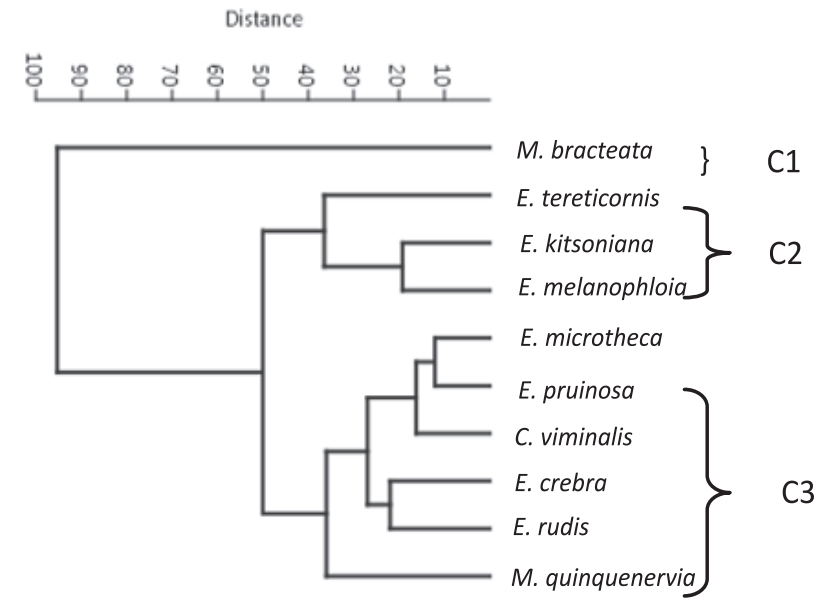

Fig. 1. Dendrogram showing hierarchical cluster analysis of the ten essential oils from different species of Myrtaceae species based on Euclidean linkage distance.

by plotting the pair groups using the Euclidean linkage distance method showing dissimilarity of the analyzed oils within the range $0-100$ (Fig. 1). For statistical analysis PAST (version 3.11) was applied.

The data were corrected using Abbott's formula for the mortality in the controls [32]. The mortalities were subjected to probit analyses using Minitab 17.0 to estimate $\mathrm{LC}_{50}$ and $\mathrm{LC}_{95}$ values of essential oils against $T$. castaneum. $\mathrm{LC}_{50}$ values were subjected to one-way ANOVA to determine variation in the activity of essential oils. Means were separated at the 5\% significance level using Tukey's Test.

\section{Results and Discussion}

\section{Essential Oils Yield}

Hydodistillation of fresh leaves yielded $1.7 \pm 0.1 \%$ of essential oil. The oil content of Callistemon viminalis was higher than previous reports [33-34]. The essential oils yields ranged between $0.1-1.9 \%$ and $0.1-1.3 \%$ for selected Eucalyptus and Melaleuca species, respectively (Table 2). The oil contents of E. rudis and E. crebra were in accordance with previous reports $[16,25,38$ 40]. However, in E. microtheca, E. melanophloia, E. kitsoniana, E. tereticornis, M. quinquenervia, and $M$. bracteata, oil yields were found to be in lower amounts than the previous reports [38, 41-44]. No data was available to compare oil yield of $E$. pruinosa in literature. The variability in essential oil yield can be attributed to the season of harvest and age of the leaves (immature, mature, or senescent).

\section{GC-MS Analysis}

The essential oil from $C$. viminalis leaves was found to be rich in monoterpene hydrocarbons $(59.8 \%)$, followed by oxygenated monoterpenes (37.6\%). Monoterpene hydrocarbons were represented by $\alpha$-pinene (31.4\%), p-cymene $(15.9 \%)$, limonene $(5.6 \%)$, and $\alpha$-phellandrene (4.3\%) as major constituents. Among oxygenated monoterpenes, 1,8-cineole (24.9\%) was the principal component, followed by $\alpha$-terpineol (11.2\%) (Table 3 ).

The richness of $C$. viminalis essential oil in $\alpha$-pinene conflicted with previous studies, where 1,8-cineole (47.9-82.0\%) was reported as a major constituent of the oil [33, 42-44]. Carvone, p-cymene-3-ol, 3-allyl2-methoxyphenol, nerol acetate, and eugenol methyl ether among monoterpenes, and ar. tumerone among sesquieterpenoids (although in small concentrations) have been reported for the first time in essential oil from C. viminalis.

Eucalyptus rudis, E. microtheca, and E. crebra essential oils contained 1,8-cineole (31.6-49.7\%) and a-pinene (16.9-32.5\%) as major components. Eucalyptus kitsoniana and E. pruinosa essential oils were rich in $\alpha$-pinene $(25.8-29.5 \%)$ and $p$-cymene $(8.2-24.8 \%)$. Eucalyptus melanophloia and E. tereticornis contained p-cymene (41.8-58.1\%) as a major component. The richness of E. crebra, E. rudis, E. microtheca, and E. pruinosa essential oils in 1,8-cineole and $\alpha$-pinene was in conformity with previous reports [22, 45-46]. Eucalyptus rudis oil contained higher 1,8-cineole (48.5\%) and $\alpha$-pinene $(32.5 \%)$ contents when compared to the Tunisian variety of E. rudis (19.9\% and 3.9-14.5\%, respectively). Limonene, which has been identified in E. rudis oil, was absent in the Tunisian variety of E. rudis [23, 4748]. 1,8-Cineole and $\alpha$-pinene were reported previously as prominent components in E. tereticornis essential oil contrary to $p$-cymene in evaluated E. tereticornis species [49-50]. 1,8-Cineole was reported as a principal constituent in Tunisian variety of E. kitsoniana, whereas $\alpha$-pinene has been identified as a major component in E. kitsoniana oil from Pakistan [48].

Eugenol methyl ether (82.3\%) was identified as a major compound along with a significant amount of methyl cinnamate (11.4\%) in M. bracteata essential oil. This is in agreement with a previous report [19, 41, 51]. Melaleuca quinquenervia essential oil mainly contained monoterpenes $(96.0 \%)$. The major components identified were 1,8-cineole $(31.0 \%)$, followed by $p$-cymen-8-ol $(19.7 \%)$ and $\alpha$-terpineol $(9.9 \%)$ in oxygenated monoterpene fraction, while the monoterpene hydrocarbon fraction contained $p$-cymene $(16.5 \%)$ as a major component, followed by limonene (6.8\%), $\alpha$-pinene (4.2\%), and terpinolene (4.2\%). Melaleuca quinquenervia essential oil showed similarity to the previous results as 1,8 -cineole being the major component [52-53]. However, $p$-cymen-8ol (19.7\%), linalool (1.5\%), eugenol methyl ether (1.1\%), and $\alpha$-phellandrene $(2.0 \%)$ among the monoterpenes and caryophyllene $(0.1 \%)$, caryophyllene oxide $(0.4 \%)$, and epiglobulol $(0.9 \%)$ as sesquiterpenes that were present in essential oil of M. quinquenervia have not been stated previously.

These differences in the essential oils compositions might arise from differences in environmental (climatic, seasonal, geographical) factors [54]. 
Table 2. Chemical composition of essential oils from different Myrtaceae species.

\begin{tabular}{|c|c|c|c|c|c|c|c|c|c|c|c|}
\hline \multirow{2}{*}{ Compounds } & \multirow{2}{*}{ RI } & \multicolumn{10}{|c|}{ Content (\%) } \\
\hline & & C. vim & E. cre & E. kit & E. mel & E. mic & E. pru & E.rud & E. ter & M. bra & M. qui \\
\hline$\alpha$-pinene & 932 & 31.4 & 16.9 & 25.8 & 24.1 & 31.0 & 29.5 & 32.5 & 0.7 & 0.2 & 4.2 \\
\hline Camphene & 944 & - & 0.2 & 0.2 & 0.3 & 0.6 & 0.4 & 0.1 & - & - & 0.1 \\
\hline$\beta$-pinene & 974 & - & - & - & - & - & 0.3 & - & - & - & - \\
\hline$\alpha$-phellandrene & 1,002 & 4.3 & 0.2 & 2.0 & 1.0 & $\operatorname{Tr}$ & 0.1 & $\operatorname{tr}$ & 0.3 & 0.1 & 2.0 \\
\hline$\delta$-3-carene & 1,004 & 0.2 & 0.1 & 0.2 & 0.3 & - & - & $\operatorname{tr}$ & 0.2 & $\operatorname{tr}$ & $\operatorname{Tr}$ \\
\hline$p$-cymene & 1,026 & 15.9 & 16.1 & 24.8 & 41.8 & 2.4 & 8.2 & 1.6 & 58.1 & 1.7 & 16.5 \\
\hline Limonene & 1,024 & 5.6 & 4.1 & 4.0 & 6.2 & 5.7 & 4.6 & 8.4 & - & 0.2 & 6.8 \\
\hline 1,8-cineole & 1,032 & 24.9 & 49.7 & 3.3 & 3.3 & 31.6 & 24.2 & 48.5 & 6.5 & 0.3 & 31.0 \\
\hline cis- $\beta$-ocimene & 1,043 & 0.5 & $\operatorname{Tr}$ & $\operatorname{Tr}$ & 0.0 & - & - & 0.1 & - & $\operatorname{tr}$ & 0.0 \\
\hline$\gamma$-terpinene & 1,055 & 1.3 & 0.2 & 1.2 & 0.8 & 0.1 & - & 0.2 & 0.5 & $\operatorname{tr}$ & 0.1 \\
\hline Terpinolene & 1,083 & 0.6 & 0.1 & 0.6 & 0.6 & 0.1 & $\operatorname{tr}$ & 0.1 & 0.2 & 0.3 & 4.2 \\
\hline$\alpha$-terpineol & 1,186 & 11.2 & 4.1 & 7.2 & 2.9 & 4.8 & 3.9 & 2.4 & 2.1 & 0.9 & 9.9 \\
\hline 2-caren-10-al & & - & - & - & - & - & - & - & 0.4 & - & - \\
\hline Linalool & 1,095 & 0.8 & - & $\operatorname{Tr}$ & 0.8 & - & 0.1 & - & 0.5 & 1.0 & 1.5 \\
\hline$\alpha$-campholenal & 1,127 & - & 0.1 & - & 0.1 & 0.1 & 0.1 & - & - & - & - \\
\hline Trans-pinocarveol & 1,135 & $\operatorname{Tr}$ & 2.0 & 0.2 & - & 2.2 & 1.3 & 0.9 & 0.1 & - & - \\
\hline $\begin{array}{l}\text { Camphene } \\
\text { Hydrate }\end{array}$ & 1,145 & - & 0.1 & 0.1 & 0.1 & 0.2 & 0.2 & $\operatorname{tr}$ & - & - & - \\
\hline Citronellal & 1,148 & - & - & - & - & - & - & - & - & $\operatorname{tr}$ & - \\
\hline 2(10)-pinen-3-one & - & - & 1.0 & 0.1 & 0.1 & 0.8 & 0.5 & 0.4 & - & - & - \\
\hline Borneol & 1,165 & 0.1 & 1.0 & 0.7 & 1.9 & 3.2 & 1.9 & 0.4 & 0.1 & - & - \\
\hline$p$-menthan-3-ol & 1,167 & - & - & - & - & - & - & - & - & 0.1 & - \\
\hline p-cymen-8-ol & 1,183 & 0.2 & 0.5 & 0.3 & 0.8 & 0.3 & 0.4 & 0.2 & 3.6 & 0.4 & 19.7 \\
\hline 2-Isopropenyl-5-methylhex-4-enal & 1,198 & - & - & $\operatorname{Tr}$ & - & - & - & - & - & 0.1 & 0.1 \\
\hline Citronellal & 1,223 & & - & - & - & - & - & - & - & 0.4 & - \\
\hline Carvone & 1,245 & 0.1 & - & - & - & - & - & - & - & - & - \\
\hline p-cymen-3-ol & 1,287 & 0.2 & 0.1 & 0.1 & 0.1 & $\operatorname{Tr}$ & 0.1 & 0.4 & 0.4 & - & - \\
\hline$\alpha$-cubebene & 1,345 & & - & - & - & - & - & - & - & $\operatorname{tr}$ & - \\
\hline 3-allyl,2-methoxy phenol & - & - & - & - & - & - & - & - & - & 0.3 & - \\
\hline Nerol acetate & 1,365 & 0.1 & - & - & - & - & - & 0.1 & 0.2 & $\operatorname{tr}$ & - \\
\hline$\alpha$-Copaene & 1,374 & - & - & - & - & $\operatorname{Tr}$ & - & - & 0.1 & $\operatorname{Tr}$ & - \\
\hline Methyl cinnamte & 1,379 & - & - & - & - & - & - & - & - & 11.4 & - \\
\hline Fenchol & - & - & - & - & - & - & - & $\operatorname{tr}$ & - & - & - \\
\hline Eugenol methyl ether & 1,402 & 0.2 & 0.1 & 0.2 & 0.5 & - & 0.1 & 0.8 & 0.7 & 82.3 & 1.1 \\
\hline$\beta$-Eudesmene & - & - & - & - & $\operatorname{Tr}$ & - & - & - & - & - & - \\
\hline Caryophyllene & 1,408 & $\operatorname{Tr}$ & 0.4 & $\operatorname{Tr}$ & $\operatorname{Tr}$ & $\operatorname{Tr}$ & - & - & 0.1 & & - \\
\hline$\beta$-Caryophyllene & 1,417 & $\operatorname{Tr}$ & $\operatorname{Tr}$ & $\operatorname{Tr}$ & 0.3 & 0.2 & 0.2 & 0.1 & - & $\operatorname{tr}$ & 0.1 \\
\hline Humulen- (IV) & - & - & - & - & - & 0.1 & - & - & - & - & - \\
\hline Germacrene D & 1,484 & - & $\operatorname{tr}$ & - & 0.1 & $\operatorname{Tr}$ & $\operatorname{tr}$ & 0.5 & 0.2 & 0.2 & 0.1 \\
\hline
\end{tabular}


Table 2. Continued.

\begin{tabular}{|c|c|c|c|c|c|c|c|c|c|c|c|}
\hline \multirow{2}{*}{ Compounds } & \multirow{2}{*}{ RI } & \multicolumn{10}{|c|}{ Content (\%) } \\
\hline & & C. vim & E. cre & E. kit & E. mel & E. mic & E. pru & E. rud & E. ter & M. bra & M. qui \\
\hline Epiglobulol & 1,585 & 0.1 & 2.5 & 0.5 & 6.9 & 2.5 & 9.7 & 1.0 & - & $\operatorname{tr}$ & 0.9 \\
\hline Germacrene B & 1,559 & - & $\operatorname{tr}$ & - & 2.8 & - & - & $\operatorname{tr}$ & 0.2 & $\operatorname{tr}$ & - \\
\hline$(E)$-nerolidol & & - & - & $\operatorname{Tr}$ & - & - & - & - & - & - & - \\
\hline Caryophyllene oxide & 1,582 & $\operatorname{Tr}$ & - & - & - & - & - & - & - & $\operatorname{tr}$ & 0.4 \\
\hline ar. Tumerone & - & 0.2 & - & - & - & - & - & - & - & - & - \\
\hline Di-epi- $\alpha$-cedrene & - & - & - & - & $\operatorname{Tr}$ & - & - & - & - & - & - \\
\hline Total & & 98.2 & 99.5 & 71.5 & 95.8 & 85.9 & 85.7 & 97.8 & 74.5 & 99.9 & 98.7 \\
\hline Monoterpene hydrocarbons & & 43.9 & 21.8 & 34 & 33.3 & 37.5 & 34.9 & 41.3 & 1.9 & 0.8 & 17.4 \\
\hline Oxygenated monoterpenes & & 37.2 & 58 & 11.6 & 9.2 & 42.9 & 32.2 & 52.7 & 9.9 & 2.6 & 42.4 \\
\hline Sesquiterpene hydrocarbons & & 0.3 & 0.4 & $\operatorname{tr}$ & 3.2 & 0.3 & 0.2 & 0.6 & 0.6 & 0.2 & 0.2 \\
\hline Oxygenated sesquiterpenes & & 0.3 & 2.5 & 0.5 & 6.9 & 2.5 & 9.7 & 1.0 & - & $\operatorname{tr}$ & 1.3 \\
\hline Aromatic compounds & & 16.5 & 16.8 & 25.4 & 43.2 & 2.7 & 8.7 & 2.2 & 62.1 & 96.2 & 37.3 \\
\hline Others & & - & - & $\operatorname{Tr}$ & - & - & - & - & - & 0.1 & 0.1 \\
\hline
\end{tabular}

$\mathrm{RI}=$ Retention Indices relative to C9-C25 $n$-alkanes on the DB-5 column; $\operatorname{tr}=\operatorname{trace}<0.05 \%$

*Plant abbreviations: Eucalyptus kitsoniana: E. kit; Eucalyptus crebra: E. cre; Eucalyptus melanophloia : E. mel; Eucalyptus microtheca: E. mic; Eucalyptus pruinosa: E.pru; Eucalyptus rudis: E. rud; Eucalyptus tereticornis: E.ter; M. bracteata; M. brac; M. quinqueneveria: M. qui; Callistemon viminalis : C. vim; RI : Retention Index; -: not detected; tr; traces.

Cluster analysis was carried out to examine the differences and similarities among the studied species on the basis of chemical compositions. The dendrogram sorted the essential oil samples into three clusters: $\mathrm{C} 1, \mathrm{C} 2$, and $\mathrm{C} 3$ (Fig. 1). $\mathrm{C} 1$ consisted of $M$. bracteata containing phenylpropanoids (eugenol methyl ether); $\mathrm{C} 2$ consisted of E. tereticornis, E. melanophloia, and E. kitsoniana that predominantly contained $p$-cymene; and Class $\mathrm{C} 3$ connects three genera viz. Callistemon, Eucalyptus, and Melaleuca. It consisted of E. rudis, E. microtheca, E. crebra, E. pruinosa, C. viminalis, and M. quinqueneveria, and is characterized by high 1,8-cineole content.

\section{Fumigant Activity}

The essential oils from Callistemon, Eucalyptus, and Melaleuca species exhibited significant fumigant toxicity against $T$. castaneum (Table 3). Conspecific comparison of essential oils of Melaleuca species showed variable activities against $T$. castaneum $\left(F_{1,4}=22.14\right.$, $p=0.009)$. Melaleuca bracteata $\left(\mathrm{LC}_{50}=200.3 \mu \mathrm{l} / \mathrm{L}\right)$ was more toxic than $M$. quinquenervia $\left(\mathrm{LC}_{50}=236.3 \mu \mathrm{l} / \mathrm{L}\right)$. The essential oils from Eucalyptus species also caused different mortalities in $T$. castaneum $\left(F_{6,14}=16.21\right.$, $p=0.000$ ). The $\mathrm{LC}_{50}$ values of Eucalyptus species ranged from 146.3-1046.1 $\mu \mathrm{l} / \mathrm{L}$. Eucalyptus rudis was the most lethal fumigant against $T$. castaneum $\left(\mathrm{LC}_{50}=146.3 \mu \mathrm{l} / \mathrm{L}\right)$, while E. pruinosa was the least toxic $\left(\operatorname{LC}_{50}=1046.1 \mu \mathrm{l} / \mathrm{L}\right)$ among the evaluated Eucalyptus species. The fumigant potential of $C$. viminalis could not be compared, being the single selected species from Callistemon genus. However, the overall comparison of essential oils from
Callistemon, Eucalyptus, and Melaleuca genera showed high susceptibility of T. castaneum toward all of them.

A review of literature showed few reports on insecticidal activity of selected Myrtaceae species against different insects. Ndomo et al. 2010 studied fumigant and contact toxicities of $C$. viminalis essential oil against Acanthoscelides obtectus and Callosobruchus maculates adults [55]. Various researchers have evaluated insecticidal activities of E. tereticornis essential oil from Argentina, Cuba, and Korea against Anopheles stephensi, Aedes aegypti, and Drosophila melanogaster [55-58]. Fumigant toxicity of E. rudis essential oils from Tunisia has been investigated against Ectomyelois ceratoniae [47].

The fumigant activities of evaluated essential oils could be attributed to their major volatile components (eugenol methyl ether, $p$-cymene, 1,8-cineole, $\alpha$-pinene). Eugenol methyl ether has been reported to possess insecticidal/ acaricidal activity against several insects/mites [59-60]. $p$-Cymene has also been implicated as an insecticide in some studies [61]. $\alpha$-Pinene has been known to show fumigant toxicity against Sitophilus oryzae, T. castaneum, and Triboleum confusum [62-63]. The effectiveness of 1,8-cineole has been documented against many storedproduct insects [22]. This implies that the higher the 1,8-cineole content, the lower the $\mathrm{LC}_{50}$ values and vice versa. However, $\mathrm{LC}_{50}$ values of $E$. rudis, E. microtheca, $E$. crebra, C. viminalis, and $M$. quinquenervia did not follow an inversely proportionate relationship with 1,8-cineole content. This suggests that other components present even in minor amounts contribute toward the insecticidal activity. The minor components in the evaluated oils (linalool, limonene, $\delta$-terpinene, and $\alpha$-terpineol) have 
Table 3. Fumigant toxicity of essential oils from different species of Myrtaceae after eight hours.

\begin{tabular}{|c|c|c|c|c|c|c|c|}
\hline \multirow{2}{*}{ Essential oils } & \multirow{2}{*}{$\mathrm{LC} 50(\mu \mathrm{L} / \mathrm{L}$ air $)$} & \multirow{2}{*}{$\begin{array}{c}\mathrm{LC}_{95} \\
(\mu \mathrm{l} / \mathrm{L} \text { air })\end{array}$} & \begin{tabular}{c} 
95\% Fiducial limits of $\mathrm{LC}_{50}$ \\
\cline { 5 - 8 }
\end{tabular} & & \multicolumn{4}{|c|}{ Fit of Probit line } \\
\hline C. viminalis & 257.76 & 405.29 & $368.96-463.89$ & Slope & $\mathrm{X}^{2}$ & $\mathrm{Df}$ & $\mathrm{P}$ \\
\hline E. crebra & 289.28 & 392.56 & $364.99-443.18$ & 8.25 & 1.79 & 4 & 0.618 \\
\hline E. kitsoniana & 314.23 & 440.89 & $407.23-502.58$ & 7.30 & 3.07 & 3 & 0.381 \\
\hline E. melanophloia & 615.09 & 800.45 & $761.68-867.54$ & 9.77 & 1.67 & 5 & 0.892 \\
\hline E. microtheca & 321.15 & 528.77 & $466.49-664.01$ & 4.55 & 4.92 & 3 & 0.178 \\
\hline E. pruinosa & $1,046.13$ & $1,532.67$ & $1,369.92-2,139.50$ & 6.33 & 0.01 & 2 & 0.997 \\
\hline E. rudis & 146.35 & 243.83 & $216.42-298.03$ & 4.420 & 0.56 & 2 & 0.754 \\
\hline E. tereticornis & 601.42 & 973.09 & $862.35-1,199.72$ & 4.76 & 5.96 & 3 & 0.114 \\
\hline M. bracteata & 200.32 & 281.84 & $260.64-321.37$ & 7.24 & 11.53 & 3 & 0.009 \\
\hline M. quinquenervia & 236.33 & 449.70 & $376.30-603.75$ & 3.26 & 1.32 & 3 & 0.724 \\
\hline Pyrethroid (Fury) & 186,750 & 437,520 & $157,980-217,670$ & 2.19 & 7.04 & 4 & 0.134 \\
\hline
\end{tabular}

been known for their toxicities against stored pests [64]. Thus a chemical composition and insecticidal-activity relationship deduced from our results demonstrates that the insecticidal activity of essential oils is attributed to the presence of major and minor components in the essential oils.

The low activity of E. pruinosa essential oil, although rich in 1,8-cineole and $\alpha$-pinene, could be explained on the basis of the low volatility of its active compounds as these toxic compounds exhibit their volatile properties during bioassays. Similarly, the good activity of $M$. bracteata essential oil with eugenol methyl ether, a phenylpropanoid derivative, and low volatile compound in comparison to terpenoids could be due to partial inhalation or ingestion through the insect body [65]. This indicates that the bioactivities of essential oils are possibly due to mixtures of constituents that have multiple effects on multiple targets. The $\mathrm{LC}_{50}$ values of studied essential oils were lower than positive control (pyrethroid), implicating their efficacy as fumigants.

\section{Conclusions}

The above findings suggest that the fumigant toxicities of essential oils of Eucalyptus, Melaleuca, and Callistemon genera were quite promising. They showed potential for use as natural fumigants for the control of the stored grain pest (T. castaneum) as an alternative to currently used synthetic fumigants. An important aspect in the commercial application of plant-essential oil-based pesticides is the availability of sufficient quantities of plant material. These selected species are fast growing and widely cultivated in Pakistan. Moreover, the essential oil yield of the most toxic species in the present study ( $E$. rudis, $M$. bracteata, M. quinquenervia, and C. viminalis) is fairly good, supporting feasibility of their exploitation as natural fumigants. However, further investigations are needed in the future to determine the safety of essential oils to humans.

\section{Acknowledgements}

The authors are thankful to Prof. Dr. A.N. Khalid in the herbarium, University of the Punjab, Lahore, for identifying plants and authenticating the specimens.

\section{References}

1. NADEEM M.K., ANJUM F.M., AMIR R.M., KHAN M.R., HUSSAIN S., JAVED M.S. An overview of anti-nutritional factors in cereal grains with special reference to wheat-A review. Pakistan Journal of food Sciences 20 (1-4), 54, 2010.

2. SINGH V. Phytochemical based pesticides as Grain Protectants. International Journal of Scientific and Research Publications 6 (6), 468, 2016.

3. SALEEM S., HASAN A., SAGHEER M., SAHI T.S. Insecticidal Activity of Essential Oils of Four Medicinal Plants against Different Stored Grain Insect Pests. Pakistan Journal of Zoology 46 (5), 1407, 2014.

4. OGENDO J.O., KOSTYUKOVSKY M., RAVID U., MATASYOH J.C. DENG A.L., OMOLO E.O., KARIUKI S.T. AND SHAAYA E. Bioactivity of Ocimum gratissimum L. oil and two of its constituents against five insect pests attacking stored food products. Journal of Stored Products Research 44 (4), 328, 2008.

5. REGNAULT-ROGER C. Botanicals in pest management. In Integrated Pest Management; Abrol, D.P., Shankar, U., Eds.; CAB International: Oxfordshire, UK, 119, 2012.

6. REGNAULT-ROGER C., VINCENT C., ARNASON J.T. Essential oils in insect control: Low-risk products in high-stakes world. Annual Review of Entomology 57, 4054, 2012. 
7. MARTINELLI L., ROSA J.M., FERREIRA C.D.S.B., NASCIMENTO G.M., DA L., FREITAS M.S., PIZATO L.C., SANTOS W., DE O., PIRES R.F., OKURA M.H., MALPASS G.R.P. Antimicrobial activity and chemical constituents of essential oils and oleoresins extracted from eight pepper species. Ciência Rural, 47 (5), 2017.

8. NATTUDURAI G., IRUDAYARAJ S.S., PAULRAJ M.G., BASKAR K., IGNACIMUTHU S. Insecticidal and Repellent Activities of Toddalia asiatica (L.) Lam. Extracts against Three Major Stored Product Pests. Entomology Ornithology and Herpetology 4,148, 2015.

9. WU Y., ZHANG W.J., HUANG D.Y., WANG Y., WEI J.Y., LI Z.H., SUN J.S., BAI J.F., TIAN Z.F., WANG P.J., DU S.S. Chemical Compositions and Insecticidal Activities of Alpinia kwangsiensis Essential Oil against Lasioderma serricorne. Molecules. 20 (12), 21939, 2015.

10. ZHANG W., YANG K., YOU C., WANG Y., WANG C., WU Y., GENG Z., SU Y., DU S., DENG Z. Bioactivity of Essential Oil from Artemisia stolonifera (Maxim.) Komar. and Its Main Compounds against Two Stored-Product Insects. Journal of Oleo Science 64, 299, 2015.

11. SONG E., KIM J.M., LEE N.H., YANG J.Y., LEE H.S. Acaricidal and Insecticidal Activities of Essential Oils against a Stored-Food Mite and Stored-Grain Insects. Journal of Food Protection 79 (1), 174, 2016.

12. WILSON P.G., O'BRIEN M.M., GADEK P.A., QUINN C.J. Myrtaceae revisited: a reassessment of infrafamilial groups. American Journal of Botany 88, 2013, 2001.

13. CALDEFIE-CHEZET F., FUSILLIER C., JARDE T., FUSILLIER C., VASSON M.P., GUILLOT J. Potential anti-inflammatory effects of Melaleuca alternifolia essential oil on human peripheral blood leukocytes. Phytotherapy Research 20 (5), 364, 2006.

14. TERZI V., MORCIA C., FACCIOLI P., VALE G., TACCONI G., MALNATI M. In vitro antifungal activity of the tea tree (Melaleuca alternifolia) essential oil and its major components against plant pathogens. Letters in applied microbiology, 44 (6), 613, 2007.

15. SIDDIQUE S., PARVEEN Z., FIRDAUS-E-BAREEN MAZHAR S., CHAUDHARY M.N., SAEED K. Chemical Composition, Antioxidant and Antimicrobial Activities of Essential oil from Callistemon viminalis (Gaertn.) G. Don Leaves. Journal of Essential Oil Bearing Plants, 1, 2017.

16. JEMÂA J.M.B., TERSIM N., TOUDERT K.T., KHOUJA M.L. Insecticidal activities of essential oils from leaves of Laurus nobilis L. from Tunisia,Algeria and Morocco, and comparative chemical composition. Journal of Stored Products Research 48, 97, 2012.

17. FATHI A., SHAKARAMI J. Larvicidal effects of essential oils of five species of Eucalyptus against Tribolium confusum (du Val) and T. castaneum (Herbest). International Journal of Agriculture Crop Science 7 (5), 220, 2014.

18. RUSSO S., CABRERA N., CHLUDIL H., YABER-GRASS M., LEICACH S. Insecticidal activity of young and mature leaves essential oil from Eucalyptus globulus Labill. against Tribolium confusum Jacquelin du Val (Coleoptera: Tenebrionidae). Chilean Journal of Agriculture Research $\mathbf{7 5}$ (3), 2015

19. SILVA C.J., BARBOSA L.C.A., MALTHA C.R.A., PINHEIRO A.L. Comparative study of the essential oils of seven Melaleuca (Myrtaceae) species grown in Brazil. Flavour and Fragrance Journal 22 (6), 474, 2007.

20. JOSEPH J.B., PAUL I.F., ROBERT J.G., BRYNN D.H., ACHARAPORN P. Essential oil variation in Eucalyptus crebra, E. melanophloia (Myrtaceae) and their hybrids. Australian Journal of Botany 57 (5), 425, 2009.
21. LUCIA A., JUAN L.W., ZERBA E.N., HARRAND L., MARCO M., MASUH H.M. Validation of models to estimate the fumigant and larvicidal activity of Eucalyptus essential oils against Aedes aegypti (Diptera: Culicidae). Parasitology Research 110 (5), 167, 2012.

22. EBADOLLAHI A., RAHIMI-NASRABADI M., BATOOLI, H., GERANMAYEH J. Evaluation of the insecticidal activities of three Eucalyptus species cultivated in Iran, against Hyphatria cunea druty (Lepidoptera: Arctiidae). Journal Plant Protection Research 53 (4), 347, 2013.

23. SLITI S., AYADI S., KACHOURI F., KHOUJA M.A., ABDERRABBA M., BOUZOUITA N. Leaf essential oils chemical composition, antibacterial and antioxidant activities of Eucalyptus camaldulensis and E. rudis from korbous (Tunisia). Journal of Materials and Environmental Sciences 6 (2), 531, 2015.

24. FAO. Land and Plant Nutrition Management Service. http://www.fao.org. 2013.

25. IRAM N., ARSHAD M., AKHTER N. Evaluation of botanical and synthetic insecticide for the control of Tribolium castaneum (Herbst) (Coleoptera: Tenebrionidae). Bioassay, 8 (3), 2013.

26. HASHMI A.A. Insect Pest Management. In: The $21^{\text {st }}$ Century. Directorate of publication, NARC, Park Road, Islamabad, Pakistan: 187, 2001.

27. ABDUL G. Flora of Pakistan, 219. 2006.

28. EDQM. European Pharmacopoeia, $5^{\text {th }}$ ed.; Council of Europe: Strasbourg, France, 2005.

29. MASS SPECTRAL LIBRARY NIST/EPA/NIH: USA,. http://www.nist.gov/srd/nlstla.htm. 2001.

30. ADAM R.P. Identification of essential oils components by gas chromatography/quadrupole mass spectroscopy. Allured Publishing Corp, Carol Stream, IL, 2001.

31. PIRES J., DE MORAIS J., DE BORTOLI E.S. Toxicidade de oleos essenciais de Eucalyptus spp. sobre Callosobruchus maculates (Fabr., 1775) (Coleoptera: Bruchidae). Revista de Biologia e Ciências da Terra 6 (1), 96, 2006.

32. ABBOTT W.S. A method for computing the effectiveness of an insecticide. Journal of Economic and Entomolology 18, 265,1925

33. OYEDEJI O.O., LAWAL O.A., SHODE F.O., OYEDEJI A.O. Chemical composition and antibacterial activity of the essential oils of Callistemon citrinus and Callistemon viminalis from South Africa. Molecules 14 (6), 1990, 2009.

34. GOHAR A.A., MAATOOQ G.T., GADARA S.R., ABOELMAATY W.S. The profile and antimicrobial activity of the essential oil from Callistemon viminalis (Sol. Ex Gaertner) G.Don Ex Loudon leaves. E3 Journal of Biotechnology and Pharmaceutical Research 5, 7, 2014.

35. AHMAD N.R., HANIF M.A., RASHID U. Chemical Compositional and Intra Provenance Variation for Content of Essential Oil in Eucalyptus microtheca. Asian Journal of Plant Sciences 4 (5), 519, 2005.

36. HAQ N.B., ZAFAR I., SHAHZAD A.S.C., IFTIKHAR H.B. Variations in Oil Potential and Chemical Composition of Eucalyptus microtheca Among Different Districts of Punjab-Pakistan. International Journal of Agriculture and Biology 9 (1), 13, 2007.

37. ELAISSI A., MEDINI H., KHOUJA M.L., SIMMONDS M., LYNEN F., FARHAT F., CHEMLI R., SKHIRI F.H. Variation in volatile leaf oils of seven Eucalyptus species harvested from Zerniza arboreta (Tunisia). Chemistry and Biodiversity 8 (2), 362, 2011.

38. BACHHETI R.K., ARCHANA J., ARJUN S. Oil content variation and antimicrobial activity of Eucalyptus leaves oils 
of three different species of dehradun, Uttarakhand, India, International Journal of Chemtech Research 3 (2), 625, 2011.

39. PINO O., SÁNCHEZ Y., ROJAS M.M., RODRÍGUEZ H., ABREU Y., DUARTE Y., MARTÍNEZ B., PETEIRA B., CORREA T.M., MARTÍNEZ D. Chemical composition and pesticidal activity of Melaleuca quinquenervia (cav) S.T. Blake Essential Oil. Revista de Protección Vegetal 26 (3), 177, 2011.

40. GHAFFAR A., YAMEEN M., KIRAN S., KAMAL S., JALAL F., MUNIR B., SALEEM S., RAFIQ N., AHMAD, A., SABA I., JABBAR A. Chemical Composition and invitro Evaluation of the Antimicrobial and Antioxidant Activities of Essential Oils Extracted from Seven Eucalyptus Species. Molecules 20 (11), 20487, 2015.

41. ALMARIE A., MAMAT A., RUKUNUDIN I. Chemical composition and herbicidal effects of Melaleuca bracteata F. Muell. Essential oil against some weedy species. International Journal of Scientific and Engineering Research 7 (1), 507, 2016.

42. SILVA C.J., BARBOSA L.C., DEMUNER A.J., MONTANARI R.M., PINHEIRO A.L, DIAS I., ANDRADE N.J. Chemical composition and antibacterial activities from the essential oils of Myrtaceae species planted in Brazil. Quimica Nova. 33 (1), 104, 2010.

43. SALEM M.Z.M., ALI H.M., SHANHOREY N.A.E., MEGEED A.A. Evaluation of extracts and essential oil from Callistemon viminalis leaves: Antibacterial and antioxidant activities, total phenolic and flavonoid contents. Asian Pacific Journal of Tropical Medicine 6 (10), 785, 2013.

44. OLIVEIRA C.M., CARDOSO1 M.G., FIGUEIREDO A.C.S., CARVALHO M.L.M., MIRANDA C.A.S.F., ALBUQUERQUE L.R.M. Chemical Composition and Allelopathic Activity of the Essential Oil from Callistemon viminalis (Myrtaceae) Blossoms on Lettuce (Lactuca sativa L.) Seedlings. American Journal of Plant Science 5, 3551, 2014.

45. ISIAKA A.O., NURENI O., KASALI A., WILFRIED A. Volatile constituents from the leaves of Eucalyptus cloeziana $\mathrm{F}$. Muell andE. propinqua Deane \& Maiden from Nigeria. Flavour and Fragrance Journal 20, 637, 2005.

46. SEFIDKON F., ASSAREH M.H., ABRAVESH Z., BARAZANDEH M.M. Chemical Composition of the Essential Oils of Four Cultivated Eucalyptus Species in Iran as Medicinal Plants (E. microtheca, E. spathulata, E. largiflorens and E. torquata). Iranian Journal of Pharmaceutical Research 6 (2), 135, 2007.

47. HAOUEL S., MEDIOUNI-BEN JEMÂA J., KHOUJA M.L. Postharvest control of the date moth Ectomyelois ceratoniae using eucalyptus essential oil fumigation. Tunisian Journal of Plant Protection 5, 201, 2010.

48. ELAISSI A., ROUIS Z., MABROUK S., SALAH K.B.H., AOUNI M., KHOUJA M.L., FARHAT F., CHEMLI R., HARZALLAH-SKHIRI F. Correlation Between Chemical Composition and Antibacterial Activity of Essential Oils from Fifteen Eucalyptus Species Growing in the Korbous and Jbel Abderrahman Arboreta (North East Tunisia). Molecules 17 (3), 3044, 2012.

49. PINO J.A., MARBOT R., QUERT R., GARCIA H. Study of essential oils of Eucalyptus resinifera, E. tereticornis and Corymbia maculata (Hook.) grown in Cuba. Flavour and Fragrance Journal 17, 1, 2002.

50. KAUR S., SINGH H.P., BATISH D.R., KOHLI R.K. Chemical characterization, antioxidant and antifungal activity of essential oil from Eucalyptus tereticornis. Journal of Medicinal Plant Research 19 (19), 4788, 2011.
51. YE Z.M., LIU X., SHEN M.J., CHEN J.Y., CHEN X.D., LI Y.Y., et al. Optimization of Process for Extraction from Melaleuca bracteata Essential Oil with Organic Solvent and Chemical Composition Identify. Chinese Journal of Tropical Crops 35, 992, 2014.

52. TRILLES B.L., BOMBARDA I., BOURAÏMA-MADJEBI S., RAHARIVELOMANANA P., BIANCHINI J.P., EMILE GAYDOU M.E. Occurrence of various chemotypes in niaouli Melaleuca quinquenervia (Cav.) S. T. Blake essential oil from New Caledonia. Flavour and Fragrance Journal 21 (4), 677, 2006.

53. PANJA A.R.R., JEAN P.B., EMILE M.G. Main Industrial Niaouli (Melaleuca quinquenervia) Oil Chemotype Productions from Madagascar. Journal of Essential Oil Research 3, 261, 2008.

54. MECHERGUI K., COELHO J.A., SERRA M.C., LAMINE S.B., BOUKHCHINA S., KHOUJA M.L. Essential oils of Origanum vulgare L. subsp. glandulosum (Desf.) Ietswaart from Tunisia: chemical composition and antioxidant activity. Journal of the Science of Food and Agriculture 90, 1745, 2010.

55. NDOMO A., TAPONDJOU L., NGAMO L., HANCE T. Insecticidal activities of essential oil of Callistemon viminalis applied as fumigant and powder against two bruchids. Journal of Applied Entomology, 134 (4), 333, 2010.

56. NATHAN S.S. The use of Eucalyptus tereticornis Sm.(Myrtaceae) oil (leaf extract) as a natural larvicidal agent against the malaria vector Anopheles stephensi Liston (Diptera: Culicidae). Bioresource technology, 98 (9), 1856, 2007.

57. LUCIA A., LICASTRO S., ZERBA E., MASUH H. Yield, chemical composition, and bioactivity of essential oils from 12 species of Eucalyptus on Aedes aegypti larvae. Entomologia experimentalis et applicata, 129, 107, 2008.

58. MURILLO-ARANGO W., ARAQUE MARÍN P., HENAO MURILlO B., PELÁEZ JARAMILlO C.A. Actividad insecticida de una emulsión aceite/agua del aceite esencial de Eucalyptus tereticornis. Revista Cubana de Plantas Medicinales 18 (1), 109, 2013.

59. CHANG K.S., SHIN E.H., PARK C., AHN Y.J. Contact and fumigant toxicity of Cyperus rotundus steam distillate constituents and related compounds to insecticidesusceptible and -resistant Blattella germanica. Journal of Medical Entomology 49, 631, 2012.

60. IMAI T., MASUDA R. Insecticidal activities of methyleugenol and $\beta$-asarone, from the herbal medicines Saishin and Sekishōkon, and other alkoxy-propenylbenzene derivatives against the cigarette beetle Lasioderma serricorne (Coleoptera: Anobiidae). Applied Entomology and Zoology 1-6, doi:10.1007/s13355-016-0466-8, 2016.

61. ZHU W.X., ZHAO K., CHU S.S., LIU Z.L. Evaluation of essential oil and its three main active ingredients of Chinese chenopodium ambrosioides (family: Chenopodiaceae) against Blattella germanica. Journal of Arthropod-Borne Diseases 6 (2), 90, 2012.

62. SUTHISUT D., FIELDS P.G., CHANDRAPATYA A. Fumigant toxicity of essential oils from three Thai plants (Zingiberaceae) and their major compounds against Sitophilus zeamais, Tribolium castaneum and two parasitoids. Journal of Stored Products Research 47 (3), 222, 2011.

63. CHAUBEY M.K. Acute, Lethal and Synergistic Effects of Some Terpenes against Tribolium castaneum Herbst (Coleoptera: Tenebrionidae). Ecologia Balkanica 4 (1), 53, 2012. 
64. STAMAPOULOS D.C., DAMOS P., KARAGIANIDOU, G. Bioactivity of five monoterpenoid vapours to Tribolium confusum (du Val) (Coleoptera: Tenebrionidae). Journal of Stored Products Research 43 (4), 571, 2007.
65. NENAAH G.E. Chemical composition, toxicity and growth inhibitory activities of essential oils of three Achillea species and their nano-emulsions against Tribolium castaneum (Herbst). Industrial Crops Products 53, 252e260. 2014. 